\title{
Influence of PPAR- $\alpha$ Agonist Fenofibrate on Insulin Sensitivity and Selected Adipose Tissue-derived Hormones in Obese Women with Type 2 Diabetes
}

\author{
K. ANDERLOVÁ ${ }^{1}$, R. DOLEŽALOVÁ ${ }^{1}$, J. HOUSOVÁ ${ }^{1}$, L. BOŠANSKÁ ${ }^{1}$, \\ D. HALUZÍKOVÁ ${ }^{2}$, J. KŘEMEN ${ }^{1}$, J. ŠKRHA ${ }^{1}$, M. HALUZÍK ${ }^{1}$ \\ ${ }^{1}$ Third Department of Medicine and ${ }^{2}$ Department of Sports Medicine, First Faculty of Medicine, \\ Charles University, Prague, Czech Republic
}

Received July 3, 2006

Accepted September 4, 2006

On-line available December 19, 2006

\begin{abstract}
Summary
PPAR- $\alpha$ agonists improve insulin sensitivity in rodent models of obesity/insulin resistance, but their effects on insulin sensitivity in humans are less clear. We measured insulin sensitivity by hyperinsulinemic-isoglycemic clamp in 10 obese females with type 2 diabetes before and after three months of treatment with PPAR- $\alpha$ agonist fenofibrate and studied the possible role of the changes in endocrine function of adipose tissue in the metabolic effects of fenofibrate. At baseline, body mass index, serum glucose, triglycerides, glycated hemoglobin and atherogenic index were significantly elevated in obese women with type 2 diabetes, while serum HDL cholesterol and adiponectin concentrations were significantly lower than in the control group $(n=10)$. No differences were found in serum resistin levels between obese and control group. Fenofibrate treatment decreased serum triglyceride concentrations, while both blood glucose and glycated hemoglobin increased after three months of fenofibrate administration. Serum adiponectin or resistin concentrations were not significantly affected by fenofibrate treatment. All parameters of insulin sensitivity as measured by hyperinsulinemic-isoglycemic clamp were significantly lower in an obese diabetic group compared to the control group before treatment and were not affected by fenofibrate administration. We conclude that administration of PPAR- $\alpha$ agonist fenofibrate for three months did not significantly affect insulin sensitivity or resistin and adiponectin concentrations in obese subjects with type 2 diabetes mellitus. The lack of insulin-sensitizing effects of fenofibrate in humans relative to rodents could be due to a generally lower PPAR- $\alpha$ expression in human liver and muscle.
\end{abstract}

Key words

Fenofibrate $\bullet$ Insulin sensitivity $\bullet$ Adiponectin $\bullet$ Resistin $\bullet$ Diabetes

\section{Introduction}

Peroxisome proliferators-activated receptors (PPARs) belong to the nuclear receptor superfamily of ligand-activated transcription factors (Torra et al. 2001). PPARs regulate lipid and glucose metabolism, cell proliferation and differentiation, inflammation and numerous other processes. To date, three different 
subtypes of PPARs have been identified: PPAR- $\alpha$, PPAR- $\gamma$ and PPAR- $\delta / \beta$ (Kersten et al. 2000). PPAR- $\gamma$ is expressed most abundantly in adipose tissue and is considered an essential regulator of adipocyte differentiation and its endocrine function (Saltiel and Olefsky 1996, Olefsky 2000). In addition to its action in adipose tissue numerous direct effects have been documented in the muscle, liver and other tissues (Gavrilova et al. 2003, Matsusue et al. 2003, Norris et al. 2003). PPAR- $\gamma$ agonists - thiazolidinediones are used as insulin-senziting drugs in the treatment of type 2 diabetes mellitus. PPAR- $\beta / \delta$ occurs practically in all tissues and plays a role in the organ development, embryo implantation, myelinization of corpus callosum, epidermal cell proliferation and lipid metabolism (Peters et al. 2000). PPAR- $\alpha$ is expressed in brown adipose tissue, liver, kidney, heart, muscle tissue and gastrointestinal tract and has been recognized as a master regulator of lipid metabolism (Lee et al. 1995, Fruchart et al. 2001, Gilde et al. 2003). Its activation increases transcription of genes involved in transport and oxidation of free fatty acids. Exogenous ligands of PPAR- $\alpha-$ fibrates - have been used for many years as effective hypolipidemic drugs with major triglyceride and free fatty acid lowering effects (Fruchart et al. 2001).

A number of recent studies underlined the close interrelationships between obesity/insulin resistance, type 2 diabetes, dyslipidemia with increased triglyceride and free fatty acid levels and decreased HDL cholesterol levels and several other pathological states commonly referred to as metabolic or Reaven's syndrome (Reaven 1988, 1992). Furthemore, ectopic lipid storage in nonadipose tissues together with endocrine dysfunction of adipose tissue have been demonstrated as major causes of insulin resistance at the postreceptor level of insulin signaling cascade (Ravussin and Smith 2002, Shulman 2000). Another possible etiopathogenetic mechanism interconnecting different pathologies within metabolic syndrome represents disturbed endocrine secretion of adipose tissue (Haluzík et al. 2004, Havel 2002, Housa et al. 2006, Housová et al. 2005).

Several experimental studies including the results of our group demonstrated that activation of PPAR- $\alpha$ decreased ectopic lipid content in the liver and muscle tissues with subsequent improvement in insulin sensitivity in obese mice (Guerre-Millo et al. 2000), obese rats (Lee et al. 2002), lipoatrophic mice (Chou et al. 2002) and mice with insulin resistance induced by muscle overexpression of dominant negative form of
IGF-1 receptor (MKR mice) (Kim et al. 2003). Furthermore, fenofibrate treatment of MKR mice not only increased their insulin sensitivity but also improved their insulin secretion (Kim et al. 2003).

The results of experimental studies focused on the influence of PPAR- $\alpha$ agonist on insulin sensitivity contrast with controversial findings of clinical studies that failed to provide convincing evidence on the consistent effects of PPAR- $\alpha$ activation on insulin sensitivity (Haluzík and Haluzík 2006). It has to be mentioned that most of these studies did not measure changes of insulin sensitivity by the glucose clamp method and some of them utilized less potent fibrates relative to those currently used in clinical practice. Here we tested the hypothesis that treatment with a potent PPAR- $\alpha$ agonist fenofibrate could improve insulin sensitivity in obese women with type 2 diabetes and we explored the possible role of the changes of endocrine function of adipose tissue in this process.

\section{Methods}

\section{Studied subjects}

Ten obese females with type 2 diabetes mellitus and serum triglyceride concentrations above $2.0 \mathrm{mmol} / \mathrm{l}$ and 10 age-matched healthy normal-weight control women were included in the study. Their body weight remained stable for at least three months before the beginning of the study. The patients were treated with diet, metformin alone or combination of metformin and glimepiride. The diabetic medication remained unchanged three months before the start throughout the entire study. None of the studied subjects suffered from any acute infection. Written informed consent was provided by all participants before being enrolled in the study. The study was approved by the Human Ethical Review Committee, First Faculty of Medicine and General University Hospital, Prague, Czech Republic.

\section{Study protocol}

Measurements of clinical and hormonal parameters in type 2 diabetes patients were performed at baseline and after 3 months of treatment with PPAR- $\alpha$ agonist - fenofibrate (200 mg, Lipanthyl 267M). Control subjects were examined only once and received no treatment.

\section{Anthropometric examination and blood sampling}

All subjects were measured and weighed, the 
body mass index was calculated and blood samples were withdrawn after overnight fasting. Serum was obtained by centrifugation and stored in aliquots at $-70{ }^{\circ} \mathrm{C}$ until further analysis.

\section{Hormonal and biochemical assays}

Biochemical parameters were measured by standard laboratory methods in the Department of Biochemistry of the General University Hospital. Serum insulin concentrations were measured by commercial RIA kit (Cis Bio Internatinal, France). Sensitivity was $2.0 \mu \mathrm{IU} / \mathrm{ml}$, and the intra- and interassay variability were $4.2 \%$ and $8.8 \%$, respectively. Serum adiponectin concentrations were measured by commercial RIA kit (Linco Research, St. Charles, Missouri, USA). Sensitivity was $1.0 \mathrm{ng} / \mathrm{ml}$, and the intra- and interassay variability were $1.78 \%$ and $9.25 \%$, respectively. Serum resistin concentrations were measured by commercial ELISA kit (BioVendor, Czech Republic). Sensitivity was $0.2 \mathrm{ng} / \mathrm{ml}$, and the intra- and interassay variability were $3.1 \%$ and $6.5 \%$, respectively.

\section{Hyperinsulinemic-isoglycemic clamp}

Hyperinzulinemic-isoglycemic clamp is based on the principle established by DeFronzo et al. (1979).
Insulin efficiency was evaluated as the amount of glucose necessary for maintaining the desired glucose levels under the conditions of constant insulin infusion calculated per unit of body weight or body surface. In case of the isoglycemic clamp the desired glucose level equals fasting blood glucose level.

At the beginning of the study, two cannulas were inserted into forearm veins on both arms. One of the cannulas was used to infuse insulin solution (20 IU HM$\mathrm{R}$ insulin in $20 \mathrm{ml} 0.9 \%$ saline solution, infusion rate: $1 \mathrm{mIU} / \mathrm{kg} / \mathrm{min}$ for patients with BMI $<30 \mathrm{~kg} / \mathrm{m}^{2}$, $40 \mathrm{mIU} / \mathrm{m}^{2} / \mathrm{min}$ for patients with BMI $>30 \mathrm{~kg} / \mathrm{m}^{2}$ ) and glucose solution (20\% glucose solution) $+20 \mathrm{ml} 7.5 \%$ $\mathrm{KCl}$ in $500 \mathrm{ml} 0.9 \%$ sodium chloride solution. Glucose infusion rate was modified according to changes of blood glucose concentration. The second cannula in the contralateral forearm was used for blood sampling for blood glucose in 5-min intervals and insulin measurements at baseline and steady-state period. Blood glucose concentration was measured by a glucometer (Super Glucocard II, Arkray, Japan). Glucose clamp was finished after $3 \mathrm{~h}$ when the "steady-state" i.e. period of stable blood glucose concentration was close or equal to the desired value for at least $30 \mathrm{~min}$.

Table 1. Anthropometric, biochemical and hormonal parameters and measures of insulin sensitivity measured by hyperinsulinemicisoglycemic clamp of control group of healthy women and obese women with type 2 diabetes mellitus before (Obese 1 ) and after three months of treatment with PPAR- $\alpha$ agonist - fenofibrate (Obese 2).

\begin{tabular}{|c|c|c|c|}
\hline & Control group & Obese 1 & Obese 2 \\
\hline$B M I\left(k g / m^{2}\right)$ & $23.90 \pm 0.75$ & $36.89 \pm 2.89 *$ & $36.78 \pm 2.76^{*}$ \\
\hline Insulin $(\mu I U / m l)$ & $24.7 \pm 3.9$ & $43.36 \pm 8.6^{*}$ & $49.54 \pm 6.7^{*}$ \\
\hline Cholesterol (mmol/l) & $5.38 \pm 0.21$ & $5.05 \pm 0.29$ & $4.84 \pm 0.31$ \\
\hline HDL-cholesterol (mmol/l) & $1.82 \pm 0.13$ & $1.07 \pm 0.08 *$ & $1.14 \pm 0.05 *$ \\
\hline LDL-cholesterol ( $\mathrm{mmol} / \mathrm{l})$ & $3.03 \pm 0.14$ & $2.71 \pm 0.28$ & $2.75 \pm 0.20$ \\
\hline Triacylglycerol (mmol/l) & $1.20 \pm 0.12$ & $2.85 \pm 0.44 *$ & $2.10 \pm 0.28 * \circ$ \\
\hline Atherogenic index & $2.07 \pm 0.20$ & $3.89 \pm 0.39 *$ & $3.24 \pm 0.18 *$ \\
\hline Blood glucose (mmol/l) & $5.00 \pm 0.25$ & $8.31 \pm 0.75^{*}$ & $9.28 \pm 0.90 * \circ$ \\
\hline Glycated hemoglobin (\%) & $3.92 \pm 0.11$ & $5.64 \pm 0.60 *$ & $6.01 \pm 0.60 * \circ$ \\
\hline$M\left(m g \cdot \mathrm{kg}^{-1} \cdot \mathrm{min}^{-1}\right)$ & $7.10 \pm 0.50$ & $3.38 \pm 0.35^{*}$ & $3.65 \pm 0.27^{*}$ \\
\hline$M_{\text {korig }}\left(m g \cdot \mathrm{kg}^{-1} \cdot \mathrm{min}^{-1}\right)$ & $6.72 \pm 0.50$ & $3.73 \pm 0.48^{*}$ & $3.63 \pm 0.38 *$ \\
\hline $\operatorname{MCR}_{g l c}\left(\mathrm{ml} \cdot \mathrm{kg}^{-1} \cdot \mathrm{min}^{-1}\right)$ & $8.00 \pm 0.78$ & $2.64 \pm 0.39 *$ & $2.43 \pm 0.36^{*}$ \\
\hline$M / I\left(m g . \mathrm{kg}^{-1} \cdot \min ^{-1}\right.$ per $\left.m U \cdot m l^{-1}\right)$ & $0.0590 \pm 0.0078$ & $0.0293 \pm 0.0045^{*}$ & $0.0215 \pm 0.0024 *$ \\
\hline$M C R_{g l c} I I\left(m l . \mathrm{kg}^{-1} \cdot \min ^{-1}\right.$ per $\left.m U \cdot m l^{-1}\right)$ & $0.0705 \pm 0.0107$ & $0.0238 \pm 0.0238 *$ & $0.0235 \pm 0.0091 *$ \\
\hline
\end{tabular}

Values are means \pm S.E.M. Statistical significance is from one-way ANOVA and Paired t-test respectively. $* p<0.05$ vs. control group, ${ }^{\circ} p<0.05$ obese group 1 vs. obese group 2. $M$ - glucose disposal rate, $M_{\text {korig }}$ - glucose disposal rate corrected for urine glucose loss, $M C R_{g \mid c}-$ metabolic clearance rate of glucose, $\mathrm{M} / \mathrm{I}, \mathrm{MCR}_{\mathrm{gl}} / \mathrm{I}$ - insulin sensitivity index. 


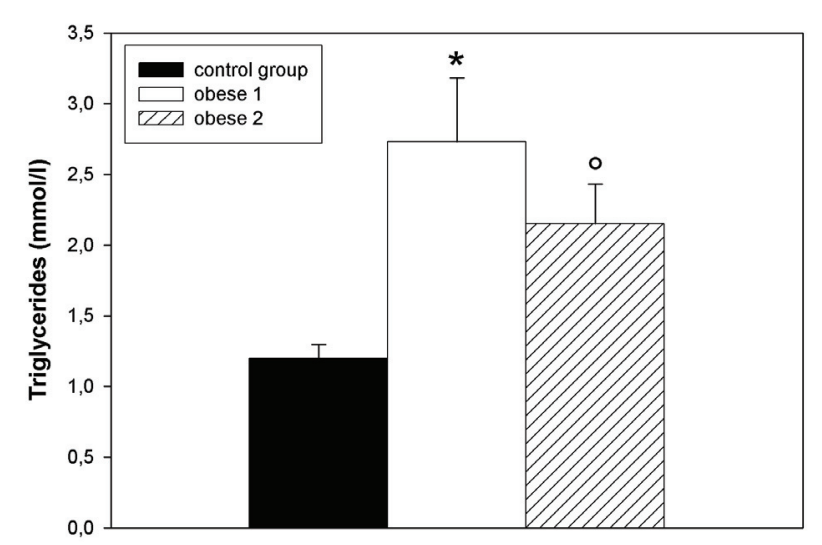

Fig. 1. Serum triglyceride concentrations $(\mathrm{mmol} / \mathrm{l})$ in control group (black bar), obese group before (open bar) and after three months of fenofibrate treatment (dashed bar). Values are mean \pm S.E.M. Statistical significance is from one-way ANOVA: $* p<0.05$ versus control group, ${ }^{\circ} p<0.05$ obese group 1 vs. obese group 2.

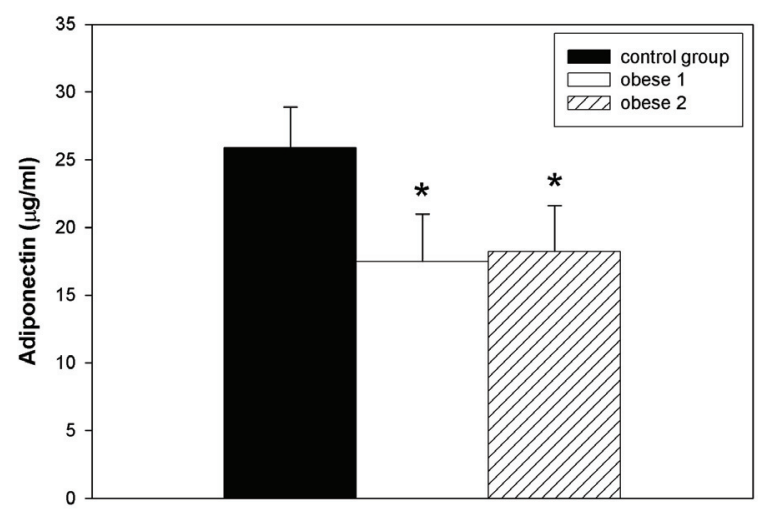

Fig. 2. Serum adiponectin concentrations $(\mu \mathrm{g} / \mathrm{l})$ in control group (black bar), obese group before (open bar) and after three months of fenofibrate treatment (dashed bar). Values are mean \pm S.E.M. Statistical significance is from one-way ANOVA: $*$ indicates $p<0.05$ versus control group.

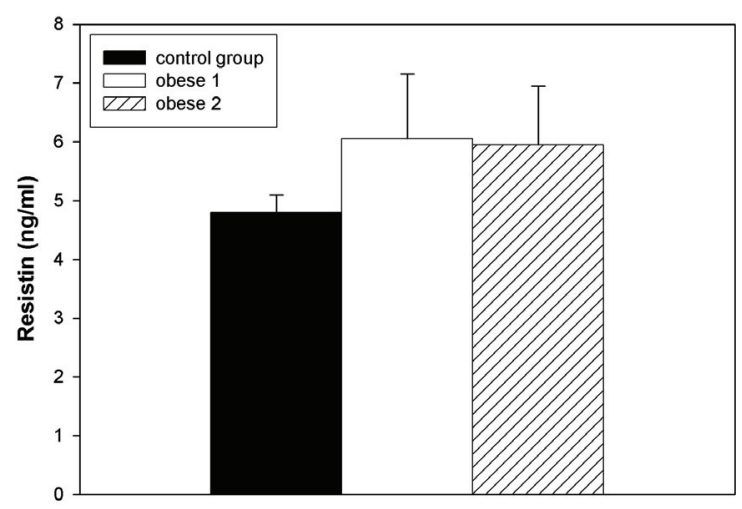

Fig. 3. Serum resistin concentrations ( $\mathrm{ng} / \mathrm{l})$ in control group (black bar), obese group before (open bar) and after three months of fenofibrate treatment (dashed bar). Values are mean \pm S.E.M.
The following parameters were calculated based on clamp results: glucose disposal rate $\left(\mathrm{M}, \mathrm{mg} \cdot \mathrm{kg}^{-1} \cdot \mathrm{min}^{-1}\right)$ was defined as the amount of glucose supplied by the infusion to maintain the desired blood glucose, glucose disposal rate $\left(\mathrm{M}_{\text {korig, }} \mathrm{mg} \cdot \mathrm{kg}^{-1} \cdot \mathrm{min}^{-1}\right)$ corrected to urine glucose loss, metabolic clearance rate of glucose $\left(\mathrm{MCR}_{\mathrm{glc}}, \mathrm{ml} \cdot \mathrm{kg}^{-1} \cdot \mathrm{min}^{-1}\right)$ was expressed as the ratio of glucose disposal rate to blood glucose concentration and the insulin sensitivity indexes $\left(\mathrm{M} / \mathrm{I}, \mathrm{mg} \cdot \mathrm{kg}^{-1} \cdot \mathrm{min}^{-1}\right.$ per

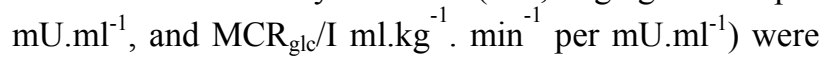
defined as the ratio of $\mathrm{M}$ or $\mathrm{MCR}_{\mathrm{glc}}$ and the average insulin concentration during the observed period (steadystate), respectively.

\section{Statistical analysis}

The statistical analysis was performed on SigmaStat software (Jandel Scientific, USA). The results are expressed as means \pm S.E.M.. Data of obese women before and after treatment with fenofibrate were compared by paired t-test. Data of obese women vs. control subjects were compared by One-Way Analysis of Variance followed by Dunnet's test.

\section{Results}

\section{Influence of fenofibrate on anthropometric and biochemical parameters}

At baseline, body mass index, serum glucose, triglycerides (Fig. 1), glycated hemoglobin concentrations and atherogenic index in the obese diabetic group were significantly higher (Table 1) while serum HDL cholesterol concentrations were significantly lower than in the control group (Table 1). Three months of treatment with fenofibrate led to significant decrease of serum triglyceride concentrations (Fig. 1), while both blood glucose and glycated hemoglobin significantly increased (Table 1). Other parameters including BMI were not affected by fenofibrate treatment (Table 1).

\section{Influence of fenofibrate on hormonal parameters}

Serum adiponectin concentrations in obese women before treatment were significantly lower than in the control group and fenofibrate treatment did not affect this parameter (Fig. 2). No differences between the obese diabetic and the control group were found in serum resistin levels either at baseline or after fenofibrate treatment (Fig. 3). 


\section{Influence of fenofibrate on insulin sensitivity}

At baseline, all parameters of insulin sensitivity as measured by hyperinsulinemic-isoglycemic clamp were significantly lower in obese diabetic women relative to control group (Table 1). Three months of fenofibrate treatment did not significantly affect any of these parameters $\left(\mathrm{M}, \mathrm{M}_{\text {korig, }}, \mathrm{MCR}_{\mathrm{glc}}, \mathrm{M} / \mathrm{I}, \mathrm{MCR}_{\mathrm{glc}} / \mathrm{I}\right)$. All parameters of insulin sensitivity remained significantly lower in obese women with type 2 diabetes mellitus compared to the control group after three months of treatment with fenofibrate.

\section{Discussion}

The aim of our study was to determine whether PPAR- $\alpha$ agonist fenofibrate affects insulin sensitivity in obese women with type 2 diabetes mellitus and whether changes of the endocrine function of adipose tissue mediate metabolic effects of this substance. The results of our study did not reveal any influence of fenofibrate on insulin sensitivity. Surprisingly, the parameters of diabetes compensation - fasting blood glucose and glycated hemoglobin - significantly increased despite clear triglyceride-lowering effect of fenofibrate. The reason for the deteriorating of diabetes compensation in our study is not clear, however, decreased insulin sensitivity after ethophyllinclofibrate treatment has previously been reported in another study (Skrha et al. 1994).

The lack of fenofibrate influence on insulin sensitivity in our study is in contrast with most but not all (Šedová et al. 2004) of previously published experimental studies. For example, it has been shown that PPAR- $\alpha$ agonist administration improved insulin sensitivity in obese mice (Guerre-Millo et al. 2000) or rats (Lee et al. 2002), mice with lipoatrophic diabetes (Chou et al. 2002) and insulin-resistant mice with muscle-specific overexpression of dominant negative form of IGF-1 receptor (Kim et al. 2003). In such studies, PPAR- $\alpha$ activation increased fatty acid oxidation in both muscles and liver with a subsequent decrease of ectopic lipid content in both tissues. As a result, insulin sensitivity was probably improved due to enhanced insulin signaling on the postreceptor level. Furthermore, in our study on mice with muscle-specific overexpression of dominant negative form of IGF-1 receptor insulin secretion was enhanced in addition to improvement of insulin sensitivity (Kim et al. 2003).

Despite quite convincing experimental data in favor of insulin-sensitizing effects of PPAR- $\alpha$ activation (Guerre-Millo et al. 2000, Chou et al. 2002, Kim et al. 2003), clinical studies performed to date have failed to unambiguously demonstrate the same effects in humans. Although some studies (Ferrari et al. 1977, Murakami et al. 1984) showed improvement of glucose tolerance and/or insulin sensitivity, other studies failed to confirm this (Rizos et al. 2002, Whitelaw et al. 2002) similarly as our current study. Škrha et al. (1994) observed even worsening of insulin sensitivity after administration of ethophyllinclofibrate for 12 weeks. The reason for discrepancies between experimental and clinical data could be explained by interspecies differences namely the different level of PPAR- $\alpha$ expression in rodent and human tissues. While in rodents PPAR- $\alpha$ expression especially in the liver is very high, its expression in human muscle and liver is much lower (Loviscach et al. 2000). Furthemore, long-term PPAR- $\alpha$ agonist administration in most rodent models of obesity significantly reduces the body fat content (Guerre-Millo et al. 2000) which in turn may lead to improvement of insulin sensitivity by an indirect mechanism such as decreased free fatty acid concentrations and/or modulation of endocrine functions of the adipose tissue. Indeed, we and others have demonstrated that PPAR- $\alpha$ activation besides reducing body adiposity increased the expression of adiponectin receptor 1 in adipose tissue which may enhance adiponectin insulin-sensitizing effects despite no change in circulating adiponectin levels (Haluzík et al. 2006, Tsuchida et al. 2005) Interestingly, in our experimental study, an improvement of insulin sensitivity after fenofibrate treatment was accompanied by paradoxical increase of circulating levels of another adipose tissue-derived hormone resistin that normally decreases insulin sensitivity (Haluzík et al. 2006). No such changes occurred in our group of obese diabetic women after fenofibrate treatment. It has to be stressed that despite clear triglyceride- and free fatty acidlowering effects in humans none of the clinical studies including huge clinical trials focused on the cardiovascular effects of fibrates reported decreased body weight or body fat content after long-term fibrate administration.

Lack of a direct effect of fibrates on adipose tissue in humans was also demonstrated in this study. In obese women with type 2 diabetes no change in body weight or body mass index occurred after the treatment with fibrate. Furthermore, fenofibrate administration had no influence on the circulating levels of adipose tissue- 
derived hormones adiponectin and resistin.

It has to be mentioned that our study has several limitations that need to be considered when interpreting the data. Firstly, it was performed on a relatively small number of subjects. Secondly, the changes of insulin sensitivity and other parameters were assessed after three months. This time period of fenofibrate treatment was long enough to decrease circulating triglyceride levels, but may not have been sufficient for the effects on insulin sensitivity. The above mentioned arguments may also hold true for the surprising worsening of diabetes compensation that had occurred in our study. Clearly, more prolonged studies on a greater number of subjects are needed for further clarification of the role of PPAR- $\alpha$ activation in the control of insulin sensitivity in humans.
In conclusion, our study on a limited number of subjects failed to demonstrate any change in insulin sensitivity after 3-month administration of fenofibrate. Furthermore, despite a significant decrease of circulating triglyceride levels no change in endocrine function of adipose tissue as measured by serum adiponectin and resistin concentrations had occurred. Thus, our study underlines the interspecies differences in PPAR- $\alpha$ agonist effects between rodents and humans and indicates that in contrast to rodents no direct effects of fibrates on adipose tissue are present in humans.

\section{Acknowledgements}

Supported by Research Project of MH CR MZO 000064165.

\section{References}

CHOU CJ, HALUZÍK M, GREGORY C, DIETZ KR, VINSON C, GAVRILOVA O, REITMAN ML: WY14,643, a peroxisome proliferator-activated receptor alpha (PPAR $\alpha$ ) agonist, improves hepatic and muscle steatosis and reverses insulin resistance in lipoatrophic A-ZIP/F-1 mice. J Biol Chem 277: 24484-24489, 2002.

DEFRONZO RA, TOBIN JD, ANDRES R: Glucose clamp technique: a method for quantifying insulin secretion and resistance. Am J Physiol 237: E214-E223, 1979.

FERRARI C, FREZZATI S, ROMUSSI M, BERTAZZONI A, TESTORI GP, ANTONINI S, PARACCHI A: Effects of short-term clofibrate administration on glucose tolerance and insulin secretion in patients with chemical diabetes or hypertriglyceridemia. Metabolism 26: 129-139, 1977.

FRUCHART JC, STAELS B, DURIEZ P: PPARs, metabolic disease and atherosclerosis. Pharmacol Res 44: 345-352, 2001.

GAVRILOVA O, HALUZÍK M, MATSUSUE K, CUTSON JJ, JOHNSON L, DIETZ KR, NICOL CJ, VINSON C, GONZALEZ FJ, REITMAN ML: Liver peroxisome proliferator-activated receptor $\gamma$ contributes to hepatic steatosis, triglyceride clearance, and regulation of body fat mass. J Biol Chem 278: 34268-34276, 2003.

GILDE AJ, VAN DER LEE KA, WILLEMSEN PH, CHINETTI G, VAN DER LEIJ FR, VAN DER VUSSE GJ, STAELS B, VAN BILSEN M: Peroxisome proliferator-activated receptor (PPAR) $\alpha$ and PPAR $\beta / \delta$, but not PPAR $\gamma$, modulate the expression of genes involved in cardiac lipid metabolism. Circ Res 92: 518-524, 2003.

GUERRE-MILLO M, GERVOIS P, RASPE E, MADSEN L, POULAIN P, DERUDAS B, HERBERT JM, WINEGAR DA, WILLSON TM, FRUCHART JC, BERGE RK, STAELS B: Peroxisome proliferator-activated receptor alpha activators improve insulin sensitivity and reduce adiposity. J Biol Chem 275: 16638-16642, 2000.

HALUZÍK MM, HALUZÍK M: PPAR-alpha and insulin sensitivity. Physiol Res 55: 115-22, 2006.

HALUZÍK M, PǍ̌ÍZKOVÁ J, HALUZÍK MM: Adiponectin and its role in the obesity-induced insulin resistance and related complications. Physiol Res 53: 123-129, 2004.

HALUZÍK MM, LACINOVÁ Z, DOLÍNKOVÁ M, HALUZÍKOVÁ D, HOUSA D, HOŘíNEK A, VERNEROVÁ Z, KUMŠTÝŘOVÁ T, HALUZÍK M: Improvement of insulin sensitivity after peroxisome proliferator-activated receptor-alpha agonist treatment is accompanied by paradoxical increase of circulating resistin levels. Endocrinology 147: 4517-4524, 2006.

HAVEL PJ: Control of energy homeostasis and insulin action by adipocyte hormones: leptin, acylation stimulating protein, and adiponectin. Curr Opin Lipidol 13: 51-59, 2002.

HOUSA D, HOUSOVÁ J, VERNEROVÁ Z, HALUZÍK M: Adipocytokines and cancer. Physiol Res 55: 233-244, 2006. 
HOUSOVÁ J, WILCZEK H, HALUZÍK MM, KŘEMEN J, KŘÍŽOVÁ J, HALUZÍK M: Adipocyte-derived hormones in heroin addicts: the influence of methadone maintenance treatment. Physiol Res 54: 73-78, 2005.

KERSTEN S, DESVERGNE B, WAHLI W: Roles of PPARs in health and disease. Nature 405: 421-424, 2000.

KIM H, HALUZÍK M, ASGHAR Z, YAU D, JOSEPH JW, FERNANDEZ AM, REITMAN ML, YAKAR S, STANNARD B, HERON-MILHAVET L, WHEELER MB, LEROITH D: Peroxisome proliferator-activated receptor-alpha agonist treatment in a transgenic model of type 2 diabetes reverses the lipotoxic state and improves glucose homeostasis. Diabetes 52: 1770-1778, 2003.

LEE HJ, CHOI SS, PARK MK, AN YJ, SEO SY, KIM MC, HONG SH, HWANG TH, KANG DY, GARBER AJ, KIM DK: Fenofibrate lowers abdominal and skeletal adiposity and improves insulin sensitivity in OLETF rats. Biochem Biophys Res Commun 296: 293-299, 2002.

LEE SS, PINEAU T, DRAGO J, LEE EJ, OWENS JW, KROETZ DL, FERNANDEZ-SALGUERO PM, WESTPHAL H, GONZALEZ FJ: Targeted disruption of the alpha isoform of the peroxisome proliferator-activated receptor gene in mice results in abolishment of the pleiotropic effects of peroxisome proliferators. Mol Cell Biol 15: 3012-3022, 1995.

LOVISCACH M, REHMAN N, CARTER L, MUDALIAR S, MOHADEEN P, CIARALDI TP, VEERKAMP JH, HENRY RR: Distribution of peroxisome proliferator-activated receptors (PPARs) in human skeletal muscle and adipose tissue: relation to insulin action. Diabetologia 43: 304-311, 2000.

MATSUSUE K, HALUZIK M, LAMBERT G, YIM SH, GAVRILOVA O, WARD JM, BREWER B, JR., REITMAN ML, GONZALEZ FJ: Liver-specific disruption of PPARgamma in leptin-deficient mice improves fatty liver but aggravates diabetic phenotypes. J Clin Invest 111: 737-747, 2003.

MURAKAMI K, NAMBU S, KOH H, KOBAYASHI M, SHIGETA Y: Clofibrate enhances the affinity of insulin receptors in non-insulin dependent diabetes mellitus. Br J Clin Pharmacol 17: 89-91, 1984.

NORRIS AW, CHEN L, FISHER SJ, SZANTO I, RISTOW M, JOZSI AC, HIRSHMAN MF, ROSEN ED, GOODYEAR LJ, GONZALEZ FJ, SPIEGELMAN BM, KAHN CR: Muscle-specific PPARgamma-deficient mice develop increased adiposity and insulin resistance but respond to thiazolidinediones. J Clin Invest 112: 608-618, 2003.

OLEFSKY JM: Treatment of insulin resistance with peroxisome proliferator-activated receptor gamma agonists. $J$ Clin Invest 106: 467-472, 2000.

PETERS JM, LEE SS, LI W, WARD JM, GAVRILOVA O, EVERETT C, REITMAN ML, HUDSON LD, GONZALEZ FJ: Growth, adipose, brain, and skin alterations resulting from targeted disruption of the mouse peroxisome proliferator-activated receptor $\beta(\delta)$. Mol Cell Biol 20: 5119-5128, 2000.

RAVUSSIN E, SMITH SR: Increased fat intake, impaired fat oxidation, and failure of fat cell proliferation result in ectopic fat storage, insulin resistance, and type 2 diabetes mellitus. Ann N Y Acad Sci 967: 363-378, 2002.

REAVEN GM: Role of insulin resistance in human disease. Diabetes 37: 1595-1607, 1988.

REAVEN GM: Syndrome X. Blood Press Suppl 4: 13-16, 1992.

RIZOS E, KOSTOULA A, ELISAF M, MIKHAILIDIS DP: Effect of ciprofibrate on C-reactive protein and fibrinogen levels. Angiology 53: 273-277, 2002.

SALTIEL AR, OLEFSKY JM: Thiazolidinediones in the treatment of insulin resistance and type II diabetes. Diabetes 45: 1661-1669, 1996.

ŠEDOVÁ L, ŠEDA O, KŘENOVÁ D, KŘEN V, KAZDOVÁ L: Isotretinoin and fenofibrate induce adiposity with distinct effect on metabolic profile in a rat model of the insulin resistance syndrome. Int $J$ Obes Relat Metab Disord 28: 719-725, 2004.

SHULMAN GI: Cellular mechanisms of insulin resistance. J Clin Invest 106: 171-176, 2000.

ŠKRHA J, ŠINDELKA G, HAAS T, HILGERTOVÁ J, JUSTOVÁ V: Relation between hypertriacylglycerolemia and the action of insulin in type 2 diabetes mellitus (In Czech). Cas Lek Cesk 133: 496-499, 1994.

TORRA IP, CHINETTI G, DUVAL C, FRUCHART JC, STAELS B: Peroxisome proliferator-activated receptors: from transcriptional control to clinical practice. Curr Opin Lipidol 12: 245-254, 2001. 
TSUCHIDA A, YAMAUCHI T, TAKEKAWA S, HADA Y, ITO Y, MAKI T, KADOWAKI T: Peroxisome proliferator-activated receptor (PPAR) $\alpha$ activation increases adiponectin receptors and reduces obesity-related inflammation in adipose tissue. Comparison of activation of PPAR $\alpha$, PPAR $\gamma$, and their combination. Diabetes 54: 3358-3370, 2005.

WHITELAW DC, SMITH JM, NATTRASS M: Effects of gemfibrozil on insulin resistance to fat metabolism in subjects with type 2 diabetes and hypertriglyceridaemia. Diabetes Obes Metab 4: 187-194, 2002.

\section{Reprint requests}

Martin Haluzík, Third Department of Medicine, First Faculty of Medicine, Charles University, U Nemocnice 1, 12808 Praha 2, Czech Republic. E-mail: mhalu@lf.cuni.cz 